$\begin{aligned} & \text { Науковий вісник НЛтУ України } \\ & \text { Scientific Bulletin of UNFU } \\ & \text { https://nv.nltu.edu.ua }\end{aligned}$
$\begin{aligned} & \text { https://doi.org/10.15421/40280916 } \\ & \text { Article received 16.10.2018 p. } \\ & \text { Article accepted 25.10.2018 p. } \\ & \text { УДк 332.145:336.14:338.124.4 1994-7836 (print) }\end{aligned}$

О. М. Попівняк, О. А. Ковенська

Дрогобицький державний педагогічний університет ім. Івана Франка, м. Дрогобич, Україна

\title{
ФІНАНСОВЕ РЕГУЛЮВАННЯ РОЗВИТКУ ТЕРИТОРІАЛЬНИХ УТВОРЕНЬ: МЕТОДИ ТА ІНСТРУМЕНТИ
}

\begin{abstract}
Досліджено проблему фінансового забезпечення соціального, економічного та екологічного розвитку територіальних громад України в умовах децентралізації влади; запропоновано нові підходи до визначення взаємовідносин державного бюджету з місцевими бюджетами; визначено джерела фінансових ресурсів території та проаналізовано можливості їх залучення; здійснено огляд наукових підходів українських вчених-економістів щодо класифікації джерел фінансового забезпечення територіальних громад; доведено що вирішальна роль у забезпеченні розвитку територіальних утворень належить державі та iï соціально-економічній політиці щодо збалансованого розвитку економічно відсталих та слаборозвинених територій. Досліджено сучасний інструментарій фінансового регулювання розвитку територіальних утворень в умовах децентралізації; проведено класифікацію інструментів фінансового забезпечення розвитку територій на бюджетні та позабюджетні; обгрунтовано необхідність залучення додаткових джерел фінансових ресурсів у територіальні утворення; розроблено механізми залучення потенціалу фінансово-кредитних установ території, фондового та страхового ринків для фінансування програм регіонального розвитку; розроблено механізм залучення інвестиційних ресурсів для фінансування програм регіонального розвитку; запропоновано ефективні методи формування, розподілу і перерозподілу фінансової бази регіону; систематизовано кількісні та якісні параметри фінансового забезпечення збалансованого розвитку.
\end{abstract}

Ключові слова: самофінансування; бюджетування; бюджетне фінансування; фінансові інструменти; регіональний розвиток; децентралізація влади.

Вступ. Сьогодні з проблемою фінансового забезпечення соціального, економічного та екологічного розвитку стикаються практично більшість територіальних громад України як високого, так і низького рівнів розвитку. Однією з найважливіших проблем залишається низька фінансова спроможність таких територій, причому як сільських, так і міських.

Особливо така проблема стала відчутною 3 початком в Україні процесу децентралізації влади, зміст якого полягає в розподілі повноважень між центральними i регіональними органами виконавчої влади та органами місцевого самоврядування територіальних утворень, відповідно до розробленої Концепції реформування місцевого самоврядування та територіальної організації влади, проекту змін до Конституції України, Законів України "Про внесення змін до Бюджетного кодексу України щодо реформи міжбюджетних відносин" від 28 грудня 2014 p., № 79-VIII, "Про добровільне об'єднання територіальних громад" від 5 лютого 2015 р., № 157-VIII та ін. Наприкінці грудня 2014 р. Верховна Рада України прийняла зміни до Податкового і Бюджетного кодексів України, якими запропонувала нові підходи до визначення взаємовідносин державного бюджету з місцевими бюджетами, чим значно розширила права місцевих органів влади і водночас надала їм бюджетну самостійність (Rusin, 2015). Такі зміни охоплюють насам- перед питання фінансової політики держави щодо фінансового забезпечення органів місцевого самоврядування територіальних утворень в умовах реформи міжбюджетних відносин, адже саме на них покладено велику відповідальність щодо створення умов для соціального, економічного та екологічного розвитку.

Аналіз останніх досліджень і публікацій. Проблеми фінансового регулювання регіонального розвитку та механізмів його вдосконалення докладно висвітлено в працях вітчизняних та зарубіжних науковців, зокрема: I. Вахович， І. Камінської， В. Галущак， 3. Герасимчук, М. Козоріз, О. Любіч, В. Опаріна, С. Юрія, О. Романенко. Як свідчить дослідження українських реалій у цьому напрямі, на сьогодні відсутні ефективні інструменти фінансового регулювання розвитку територіальних утворень.

Мета дослідження полягає в аналізі сучасного інструментарію фінансового регулювання територіальних утворень в умовах децентралізації.

Викладення основного матеріалу. Варто зазначити, що збалансованого розвитку територіальних утворень неможливо досягнути без його належного фінансового забезпечення. Тому насамперед потрібно визначити джерела необхідних фінансових ресурсів та проаналізувати можливості їх залучення.

Фінансові ресурси регіону є сукупністю нагрома-

\section{Інформація про авторів:}

Попівняк Оксана Мирославівна, канд. екон. наук, доцент, кафедра економіки та менеджменту. Email: popivnjak@i.ua Ковенська Оксана Аркадіївна, канд. екон. наук, доцент, кафедра економіки та менеджменту. Email: O_kovenska@meta.ua Цитування за ДСТУ: Попівняк О. М., Ковенська О. А. Фінансове регулювання розвитку територіальних утворень: методи та інструменти. Науковий вісник НЛтУ України. Серія Економічна. 2018, т. 28, № 9. С. 81-85

Citation APA: Popivnjak, O. M., \& Kovenska, O. A. (2018). Financial regulation of the development of territorial units: methods and tools. Scientific Bulletin of UNFU, 28(9), 81-85. https://doi.org/10.15421/40280916 
джень і доходів місцевих бюджетів і державних цільових позабюджетних фондів, коштів населення і коштів суб'єктів господарювання, фінансових ресурсів фінансово-кредитних установ, а також залучених фінансових ресурсів зі сторони, які використовують 3 економічною, соціальною і екологічною метою розвитку території (Vakhovych \& Kaminska, 2009). У своїй сукупності вони формують основу фінансового забезпечення розвитку окремих територій.

Багато науковців наводять три джерела фінансового забезпечення розвитку окремих територій: самофінансування, державне фінансування та бюджетування. В. Опарін виділяє самофінансування, зовнішнє фінансування та кредитування. При цьому під зовнішнім фінансуванням дослідник розуміє кошти, які виділені певним суб'єктам господарювання на безповоротній i безоплатній основі, і зазначає, що це "може бути державне фінансування з бюджету чи державних фондів цільового призначення, надходження коштів від громадських чи доброчинних фондів і організацій даної країни та 3-за кордону, гранти від громадських організацій тощо" (Oparin, 2005). О. Любіч виокремлює такі джерела: самофінансування, страхування, кредитування, безповоротне фінансування (Liubich, 2004). О. Романенко та С. Юрій - бюджетне фінансування, кредитування, самофінансування, оренду та інвестування. Погоджуємось 3 думкою І. Камінської про доцільність виділення таких джерел фінансового забезпечення регіону, як самофінансування, кредитування, бюджетне фінансування, інвестування та інші.

Очевидно, що вирішальна роль у забезпеченні розвитку територіальних утворень належить державі та іiі соціально-економічній політиці щодо збалансованого розвитку економічно відсталих та слаборозвинених територій. Тому головним джерелом у питаннях забезпечення розвитку територіальних утворень $\epsilon$ саме бюджетне фінансування. Уряду необхідно подолати розбіжність у показниках територій щодо рівня та якості життя, екологічної ситуації, зайнятості населення тощо.

Щодо фінансового регулювання як підсистеми механізму фінансового забезпечення територіальних утворень, то це $\epsilon$ сукупність методів та інструментів фінансового впливу, пов'язаних із регулюванням економічних, соціальних та екологічних процесів таких територій.

Суб'єктами фінансового регулювання $є$ :

- на макрорівні - державні органи влади та управління;

- на мезорівні - територіальні органи влади та управління;

- на мікрорівні - територіальні суб'єкти господарювання.

Фінансове регулювання визначає характер дії усього механізму фінансового забезпечення розвитку територіальних утворень і проводять його за допомогою формування та реалізації системи спеціальних фінансових інструментів.

У широкому розумінні інструмент варто розглядати як важіль, з допомогою якого здійснюється вплив на певний об'єкт. Вважаємо, що інструменти механізму фінансового забезпечення розвитку територіальних утворень варто розглядати як сукупність різноманітних регуляторів - фінансових норм, нормативів, лімітів і резервів, які підтримують та стимулюють розвиток депресивних територій. Сукупність цих інструментів регулює потоки фінансових ресурсів суб'єктів фінансовоекономічних відносин регіону, стимулюючи, підтримуючи чи стримуючи їх діяльність (Kaminska, 2009).
До фінансових інструментів забезпечення розвитку територіальних утворень відносимо сукупність управлінських механізмів, які застосовують для справедливого перерозподілу фінансів 3 метою фінансового забезпечення інструментів управління територіальним (місцевим) розвитком i спрямування діяльності інших суб'єктів регіонального розвитку.

Фінансові інструменти механізму фінансового забезпечення місцевого самоврядування представлено засобами формування доходів і здійснення видатків та включають: муніципальні цінні папери, кредити, державні соціальні стандарти, нормативи видатків, коефіцієнти формул фінансового вирівнювання, трансферти 3 державного бюджету. Також як фінансові інструменти використовують цінні папери, лізинг, ф'ючерси, опціони, франчайзинг, кредитні договори тощо, як фінансові важелі - норму рентабельності, дохід, прибуток, нормативи фінансових санкцій тощо.

Відповідно до механізму функціонування та стосунку до органів місцевої влади, інструменти фінансового забезпечення розвитку територіальних утворень поділяють на:

- бюджетні, які грунтуються на використанні державних та місцевих бюджетів як основного механізму перерозподілу ресурсів;

- позабюджетні, які грунтують на загальних господарськоправових відносинах.

Вважаємо, що основних інструментів фінансового регулювання територіальних утворень належать:

- оподаткування (вилучення частини доходів підприємств і населення до бюджету та державних цільових фондів);

- бюджетні трансферти (дотації, субвенції).

Зазначимо, що ефективність механізму фінансового забезпечення розвитку територіальних утворень залежить від цілеспрямованого вибору фінансових інструментів та дієвості їх впливу на соціальний, економічний та екологічний розвиток території.

Водночас важливим для ефективного функціонування фінансового механізму і ведення ефективної фінансової політики є можливість вільного маніпулювання фінансовими інструментами. Обмеженість тих чи інших органів влади у використанні фінансових інструментів знижує можливості адекватного реагування на макрофінансову ситуацію, не дає змоги вчасно реалізувати необхідні заходи (Lovochkin, 2004).

Механізм фінансового забезпечення розвитку територіальних утворень хоч і є об'єктивним явищем, зумовленим наявністю фінансів у соціо-еколого-економічній системі території, проте його функціонування значно залежить від того, як владні структури на територіальному рівні й у державі загалом зуміють його використати для досягнення поставлених цілей, тобто для здійснення тієї регіональної політики, яку вони реалізовують.

Також в умовах обмеженості бюджетних коштів як на регіональному, так і на державному рівнях доцільно пошукати додаткові джерела залучення фінансових ресурсів у територіальні утворення, а також формування та реалізації механізмів стимулювання нарощення власної фінансово-ресурсної бази регіону. Вважаємо, що серед додаткових джерел фінансових ресурсів, які необхідно залучити для фінансування програм регіонального розвитку, є такі: 
- ресурси фінансово-кредитних установ територіальних утворень;

- кошти фондового ринку та ринку позикових капіталів;

- кошти страхового ринку;

- кошти інвесторів.

Водночас, виходячи з реалій розвитку як України загалом, так і ii регіонів, такі джерела можуть сягнути перспективи внаслідок:

- підвищення ефективності використання потенціалу фінансово-кредитних установ;

• розвитку фондового ринку та ринку позикових капіталів;

- розвитку страхового ринку;

• поліпшення інвестиційно-привабливого клімату територіальних утворень.

Зупинимось на дослідженні механізмів залучення наведених вище додаткових джерел фінансування програм регіонального розвитку.

Механізми залучення потенціалу фінансово-кредитних установ територій для фінансової підтримки територіальних утворень. Найперспективнішим джерелом фінансової підтримки територіальних утворень може стати злагоджена система співпраці з фінансово-кредитними установами, адже саме вони $є$ генераторами руху фінансових ресурсів між державою та населенням.

Можливості використання державою пільгового кредитування у своїй фінансовій політиці обмежені та лише в деяких випадках держава може виділяти кошти комерційним банкам на цільове кредитування окремих суб'єктів чи заходів. Водночас комерційні банки наділені правами самостійно визначати кому, на яких умовах, надавати кредити та під які відсотки. Держава засобами грошово-кредитної політики може впливати на функціонування кредитного ринку. Основним інструментом такого впливу є регулювання вартості запозичень через облікову ставку Національного банку. Окрім цього, держава може регулювати обсяги кредитних ресурсів через механізми обов'язкових резервних вимог, які встановлюють для комерційних банків, та за допомогою операцій з цінними паперами на відкритому ринку (Oparin, 2006).

Банки та небанківські установи повинні брати безпосередню участь у розвитку територіальних утворень, задовольняючи соціально-економічні потреби населення в іпотечному кредитуванні, кредитуванні малого i середнього бізнесу, розширенні видів споживчого кредиту, страхуванні кредитів бізнесу тощо. Однак це передбачає необхідність відновлення втраченої довіри населення до користування послугами банків та небанківських установ.

Важливу роль у фінансовій підтримці потреб територіальних утворень можуть відігравати кредитні спілки, недержавні пенсійні фонди, страхові компанії, інвестиційні фонди та компанії 3 управління активами. Основне призначення кредитних спілок - сприяти пожвавленню торговельного обороту, підвищуючи купівельну спроможність населення.

Механізми залучення ресурсів фондового ринку та ринку позикових капіталів установ для фінансової підтримки територіальних утворень. У разі дефіциту власних коштів перспективи належного розвитку територіальних утворень залежать від того, наскільки вони зможуть ефективно використовувати залучені з фінансового ринку кошти. Зазвичай фінансовий ринок на переважній більшості території слаборозвинений, і частка залучених фінансових ресурсів від їх діяльності у зведеному фінансовому балансі незначна.

В економічно розвинених країнах здебільшого фондовий ринок та ринок позикових капіталів забезпечують перерозподіл основної частини фінансових ресурсів суспільства i характеризуються доволі жорстким рівнем конкуренції між розпорядниками.

В Україні ринок позикових капіталів та фондовий ринок перебувають лише на стадії формування, що $\epsilon$ наслідком недосконалості чинного законодавства та недостатньої ефективності регулювання з боку держави.

Ринок позикових капіталів визначають як сукупність спеціалізованих кредитно-фінансових установ, механізмів кредитних відносин і кредитного законодавства. Основні джерела позикового капіталу - це вільні фінансові ресурси держави, юридичних і фізичних осіб, що акумулюються переважно на депозитних рахунках.

Унаслідок того, що слаборозвинені території характеризуються низькими доходами населення, збитковістю промислових підприємств, на депозитних рахунках банків коштів для фінансування інвестицій акумулюється недостатньо. Між розпорядниками фінансових ресурсів немає повноцінної конкуренції, тому за ринками зберігається єдиний статус "ринку продавця" 3 відповідними негативними наслідками для інвесторів і користувачів. Зростання частки позикового капіталу та ресурсів фондового ринку в бюджеті територіальних утворень є одним 3 альтернативних джерел збільшення фінансових ресурсів та їх перерозподілу.

Залучення ресурсів фондового ринку для фінансової підтримки територіальних утворень потребує:

- забезпечення захисту прав інвесторів;

- інституалізації фондового ринку;

- розбудови національної депозитної системи;

- розвитку інфраструктури фондового ринку;

- удосконалення правових засад випуску та обігу цінних паперів.

Механізми залучення ресурсів страхового ринку для фінансування програм регіонального розвитку. Страховий ринок є особливою сферою фінансових відносин, де об'єктом купівлі-продажу виступає специфічна фінансова послуга - страховий захист різних ризиків. Страховий ринок виконує дві базові функції у розвитку територій:

- задоволення потреб держави, юридичних і фізичних осіб у страховому захисті їх майнових, а також немайнових прав та запобігання ризикам;

- мобілізація фінансових ресурсів суспільства 3 подальшим використанням їх на інших фінансових ринках.

На нашу думку, розвиток страхового ринку забезпечить захист населення та суб'єктів господарської діяльності від різних ризиків (індивідуальних, майнових i відповідальності) завдяки таким операціям:

- соціальному страхуванню фізичних осіб від можливого зниження особистого доходу страхувальника на тимчасовій (тимчасова непрацездатність) або постійній (вихід на пенсію) основі;

- страхування підприємницьких ризиків: комерційних ризиків у сфері товарообігу і фінансових ризиків кредитних, фондових i безпосередньо страхових (перестрахування) фондів;

- особисте страхування (у будь-яких формах);

- страхування відповідальності страхувальника (страхування прямої відповідальності страхувальника; страхування відповідальності третіх осіб). 
Також такі установи, не використовуючи всі кошти одразу, накопичують їх, створюючи так званий резерв коштів. Обсяг таких резервів може бути значним, тому виникає питання щодо їх розміщення.

Такі кошти резервів є важливим джерелом капітальних вкладень, що можна використати для розвитку територій. Тому місцеві органи за наявності продуманих програм, узгоджених та взаємовигідних відносин мають можливість залучати кошти для вирішення найважливіших проблем.

Механізми залучення інвестищійних ресурсів для фiнансування програм регіонального розвитку. Якщо немає необхідних фінансових ресурсів для регіонального розвитку, то важливим їх джерелом можуть стати інвестиції (Rymar, Popivniak \& Fylypiv, 2014).

У розвинених країнах основну роль у розвитку інвестиційної активності відіграють державні корпорації регіонального розвитку, головними завданнями яких $\epsilon$ :

- посилення впливу суспільного (державного і муніципального) сектора на розвиток регіону за допомогою цілеспрямованої діяльності державних і муніципальних підприємств та фірм зі змішаним капіталом;

- здійснення проектів удосконалення регіональної інфраструктури, оздоровлення соціального та економічного середовища;

- залучення інвесторів, особливо до проблемних ареалів, надання приватним підприємцям фінансової, правової та іншої допомоги, стимулювання інноваційної діяльності;

- виконання функцій банків розвитку.

Водночас зазначимо, що у світовій практиці часто використовують такі основні стимули інвестиційної активності: надання державних і муніципальних гарантій інвесторам; розвиток механізмів страхування інвестиційної діяльності; розроблення податкових інструментів стимулювання інвестицій та інші.

Висновки. Отже, механізм фінансового забезпечення та регулювання розвитку територіальних утворень відображає спроможність місцевих органів влади мобілізувати необхідні фінансові ресурси 3 різних джерел задля виконання покладених на них функцій відповідно до законодавства, а саме - збалансування потреб регіону та його фінансових можливостей.

Механізм фінансового забезпечення розвитку територіальних утворень працюватиме ефективно, якщо функціонують всі його складові як: на національному рівні, так і на рівні суб'єктів господарювання.

На національному рівні механізм фінансового забезпечення розвитку територіальних утворень передбачає визначення джерел фінансового забезпечення і моделі фінансового регулювання розвитку територіальних утворень, яка грунтується на методах розподілу (сальдовий і нормативний), та засобах регулювання, які включають такі фінансові інструменти, як: податки, збори, обов'язкові платежі, субсидії, трансферти тощо, фінансові важелі (ставка оподаткування, рівень резервування, ставка рефінансування НБУ, валютний курс тощо).

На рівні суб'єктів господарювання територіальних утворень механізм фінансового забезпечення розвитку таких територій передбачає визначення джерел фінансового забезпечення і моделі фінансового регулювання, у межах якої визначають його методи та засоби.

\section{Перелік використаних джерел}

Kaminska, I. M. (2009). Financial capacity of the regions of Ukraine in the context of European integration processes. Economic sciences. Series: Economic Theory and Economic History. Collection of scientific works of LNTU, 6(23). Part 1. Lutsk.

Liubich, O. O. (2004). Teoretychni osnovy pryiniattia finansovykh rishen na makrorivni. Kyiv: NDFI, 348 p. [In Ukrainian].

Lovochkin, S. V. (2004). Finansovyi mekhanizm makroekonomichnoho rehuliuvannia. Finance of Ukraine, 3, 19-26. [In Ukrainian].

Oparin, V. M. (2005). Finansy. (Zahalna teoriia). (2nd ed.). Kyiv: KNEU, 240 p. [In Ukrainian].

Oparin, V. M. (2006). Finansova systema Ukrainy (teoretyko-metodolohichni aspekty) . Doctoral Dissertation for Economic Sciences (08.04.01 - Finance, money circulation and credit). Kyiv, 386 p. [In Ukrainian].

Rusin, V. M. (2015). Vdoskonalennia mizhbiudzhetnykh vidnosyn v Ukraini. Upravlinnia finansamy derzhavy, rehionu, pidpryiemstva ta domohospodarstva: pohliady naukovtsiv i praktykiv: zbirnyk tez dopovidei Pershoi Internet-konferentsii. Ternopil. [In Ukrainian].

Rymar, M. V., Popivniak, O. M., \& Fylypiv, R. S. (2014). Finansovi mekhanizmy zabezpechennia rozvytku depresyvnykh terytorii: teoriia i metody. Lviv: Panorama, 260 p. [In Ukrainian].

Vakhovych, I. M., \& Kaminska, I. M. (2009). Finansova spromozhnist rehionu: diahnostyka ta mekhanizmy zabezpechennia. Lutsk: Nadstyria, 400 p. [In Ukrainian].

О. М. Попивняк, О. А. Ковенская

Дрогобычский государственный педагогический университет им. Ивана Франко, г. Дрогобыч, Украина

\section{ФИНАНСОВОЕ РЕГУЛИРОВАНИЕ РАЗВИТИЯ ТЕРРИТОРИАЛЬНЫХ}

ОБРАЗОВАНИЙ : МЕТОДЫ И ИНСТРУМЕНТЫ

Исследована проблема низкой финансовой состоятельности территориальных образований Украины в условиях децентрализации власти, смысл которой заключается в распределении полномочий между центральными и региональными органами исполнительной власти и органами местного самоуправления территориальных общин; доказана решающая роль государства и его социально-экономической политики в обеспечении развития территориальных образований. Подан инструментарий финансового регулирования развития территорий; проведена классификация инструментов финансового обеспечения территории на бюджетные и внебюджетные ресурсы; обоснована необходимость привлечения дополнительных источников финансовых ресурсов в территориальные образования; разработаны механизмы привлечения инвестиционных ресурсов, а также потенциала финансово-кредитных учреждений территории, фондового и страхового рынков для финансирования программ регионального развития. Предложен механизм финансового обеспечения развития территориальных образований, основанный на методах распределения (сальдовый и нормативный) и средствах регулирования, включая такие финансовые инструменты, как налоги, сборы, обязательные платежи, субсидии, трансферты; предложены эффективные методы формирования, распределения и перераспределения базы региона; систематизированы количественные и качественные параметры финансового обеспечения сбалансированного развития.

Ключевые слова: децентрализация власти; финансовый потенциал; финансовые ресурсы; финансовые механизмы. 
O. M. Popivnjak, O. A. Kovenska

FINANCIAL REGULATION OF THE DEVELOPMENT OF TERRITORIAL UNITS: METHODS AND TOOLS

The article investigates the mechanism of financial support for the development of territorial units with the use of financial regulation instruments. The decisive role in ensuring the development of territorial units belongs to the state and its social-economic policy regarding the balanced development of economically backward and underdeveloped territories. Therefore, the main source for the development of territorial units is budget funding. The Government needs to overcome the disparity in the indicators of the territories regarding the level and quality of life, the environmental situation, employment of the population etc. The financial instruments for the development of territorial units include a set of management mechanisms that are used for the equitable redistribution of finances in order to financially provide tools for managing territorial (local) development and directing other regional development actors. The mechanisms for attracting additional sources of funding for regional development programs include as follows: mechanisms of attraction of potential of financial and credit institutions of territories for financial support of territorial entities; mechanisms of attraction of resources of the stock market and the market of loan capital of institutions for financial support of territorial units; mechanisms of attraction of resources of the insurance market for financing of regional development programs; mechanisms for attracting investment resources to finance regional development programs. The sources of financial support are outlined, as well as models of financial regulation of territories development are considered. In the course of research, groups of financial security parameters are systematized for the purpose of balanced development of territorial units. To conclude, the mechanism of financial support for the development of territorial units will work efficiently if all its components are functioning both at the national level and at the level of economic entities.

Keywords: self-financing; budgeting; budget financing; financial instruments; regional development; financial resources; models of financial regulation. 